\title{
Analyzing the Arkansas River Caddoan Cultural Landscape
}

Robert L. Brooks

Unknown

Follow this and additional works at: https://scholarworks.sfasu.edu/ita

Part of the American Material Culture Commons, Archaeological Anthropology Commons, Environmental Studies Commons, Other American Studies Commons, Other Arts and Humanities Commons, Other History of Art, Architecture, and Archaeology Commons, and the United States History Commons

Tell us how this article helped you.

This Article is brought to you for free and open access by the Center for Regional Heritage Research at SFA ScholarWorks. It has been accepted for inclusion in Index of Texas Archaeology: Open Access Gray Literature from the Lone Star State by an authorized editor of SFA ScholarWorks. For more information, please contact cdsscholarworks@sfasu.edu. 
Analyzing the Arkansas River Caddoan Cultural Landscape

Creative Commons License

(c) $(1)(9)$

This work is licensed under a Creative Commons Attribution-NonCommercial 4.0 International License 


\title{
ANALYZING THE ARKANSAS RIVER CADDOAN CULTURAL LANDSCAPE
}

\author{
Robert L. Brooks
}

\begin{abstract}
This paper examines the Arkansas River Caddoan cultural landscape through use of "architectural grammar". Architectural grammar presents a mechanism to look at the practices of Arkansas River Caddoans as they construct their mound and residential places. Through this analysis, five different cultural landscapes were constructed: residential places, single mounds without residential occupation, single mounds with residential occupation, multiple mounds of the same construction type, and multiple mounds of different construction type. Further analysis of these places on the landscape suggest that rather than ordered hierarchy of centers, that the Caddoan cultural landscape represents an effort to build to a formalized template.
\end{abstract}

\section{Introduction}

This paper examines the cultural landscape of the Arkansas River basin Caddoan societies as presented through a GIS framework. Earlier studies examined the settlement and subsistence practices of this region (Wyckoff 1980) as well as settlement patterns/distributions (Brown, Bell, and Wyckoff 1978). More recent work by Vogel (2006) has studied ceremonial centers and mound sites using GIS analysis. My analysis builds upon Vogel's study by examining not only mound sites and ceremonial centers but also the many residential places occupied by Caddoan societies in the Arkansas River basin. The theoretical base of the analysis lies in the framework of "architectural grammar". Approximately 10 years ago, Lewis, Stout, and Wesson's (1998) introduction to Mississippian Towns and Sacred Spaces established the concept of an architectural grammar. Architectural grammar, derived from the religious and political practice of the Mississippian communities, resulted in a blue print for the ritualized construction of towns and centers. At least portions of this grammar, they argued, can be archaeologically visualized. Their consideration was focused on the built environment and did not include other elements of the cultural landscape. Knapp and Ashmore (1999: 10-13) describe constructed, conceptualized, and ideational landscapes. Constructed landscapes reflect the built environment and represent an active intervention by a group in modification of the natural landscape in some fashion. In other cases, the natural landscape may have associative religious, artistic, or social meaning. This reflects a conceptualized landscape. The third landscape form is an ideational one that takes on the role of serving as a symbolic reference for mythological histories or other group references. As theories of the cultural landscape have continued to evolve, there has been a movement away from the basic architectural grammar or built environment to one consisting of deeper, structural forms. The desire in this paper is to return to examining the cultural landscape of the town and center as cultural/sacred landscapes. Thus, this "grammar "serves as a tool by which to distinguish structural differences in the construction of residential as well as ceremonial places of the Caddoan cultural landscape. 


\section{Caddoan Cultures}

Caddoan is the term used in reference to the westernmost mound building societies of the Mississippian World (Rogers and Sabo 2004). Sites associated with this cultural expression extend from Northwest Arkansas and Northeast Oklahoma south to Northwest Louisiana and Northeast Texas - tethered around epi-centers such as Spiro Mounds in Oklahoma and the George C. Davis mound group in Texas (Figure 1a-b). Caddoan society is expressed through an arrangement of hamlets, villages, single mound sites, and mound centers distributed along principal waterways of the region. It has been recognized for some time that the Caddoan cultural landscape has notable differences from those of the greater Mississippian pattern. However, large quantities of highly prestigious funerary offerings from sites such as Spiro belie the Caddoan cultural expression as being of lessened significance in the Mississippian World. As Perttula (2009) has noted, while the Caddo (Caddoan) area is clearly involved in the Mississippian expression, there is also evidence that points to the independent development of many aspects of Caddo (Caddoan) society.

While there are differences between the Caddoan cultural landscape and that of Mississippian societies in the southeast and Midwest, there are also distinguishing characteristics between the Caddoan patterns of the Arkansas River basin and that of the Red River basin. This has led to some of us describing the Red River pattern as the Red River Caddo due to a direct cultural affiliation with known historic Caddo groups (e.g., the Hasinai, Kadohadacho, Natchitoches, Anadarko, etc) and the Arkansas River pattern as the Arkansas River Caddoan due to a lack of direct cultural affiliation with any known historic Caddo group. In fact, the Arkansas River basin Caddoan could well represent the historically known Wichita (e.g., the Tawakoni) or Kichai (c.f, Wyckoff 1985) or groups of Caddoan language speakers that did not survive into historic contact times. While this may seem confusing terminology, especially to those unfamiliar with the Caddoan area, it serves to highlight the fact that the Caddoan area should not be viewed as culturally homogenous.

Schambach has critically examined the differences between the Arkansas River basin Caddoan and the Red River basin Caddo and argued persuasively for the Arkansas River basin cultures representing a pattern that more closely parallels that of the Mississippi River valley. Based principally on material culture, he suggested that the Arkansas River basin Caddoan pattern was derived from priestly rulers traveling upstream on the Arkansas River (Schambach 1993a, 1993b, 1999). These were thought to reflect Tunican "traders/religious leaders" that ultimately resulted in an Arkansas River pattern focused around an "entrepôt" system - exchanging bison hides and other Plains goods for the religious paraphernalia associated with the Mississippian World. This view was initially challenged by Bruseth, Wilson, and Perttula (1995) who argued that little evidence exists for the presence of an entrepôt system between Spiro and towns/centers on the Red River or the Plains. I also argued that evidence for such a trade model was lacking in the archaeological data and that bison becomes an important commodity only within the later Fort Coffee phase cultures (Brooks 1996). I later suggested that although Schambach was correct in noting significant cultural distinctions between the two river basins, these differences were perhaps more related to a religious metaphor than an economic one (Brooks 2006). These distinctions certainly merit further critical examination, but in this analysis, the emphasis is on the expressions of the Caddoan cultural landscape in the Arkansas River basin.

Future work can then compare these characteristics to those that have been identified for the Red River Caddo cultures in southeastern Oklahoma (Brooks 2008). 


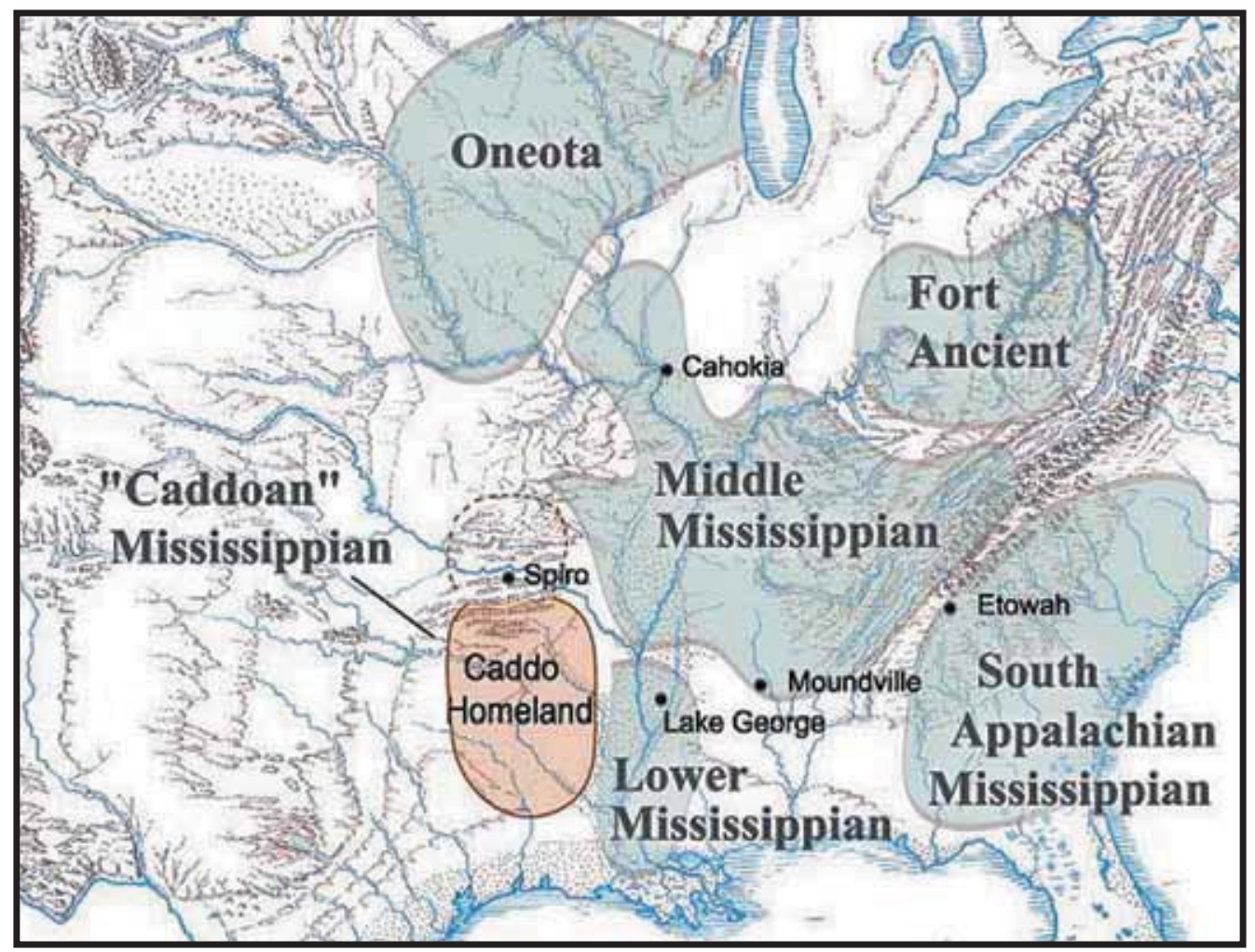

Figure 1a. Map depicitng the extent of the Mississippian cultural development (image from Texas Beyond History, http://www.texasbeyondhistory.net/tejas/fundamentals/miss.html).

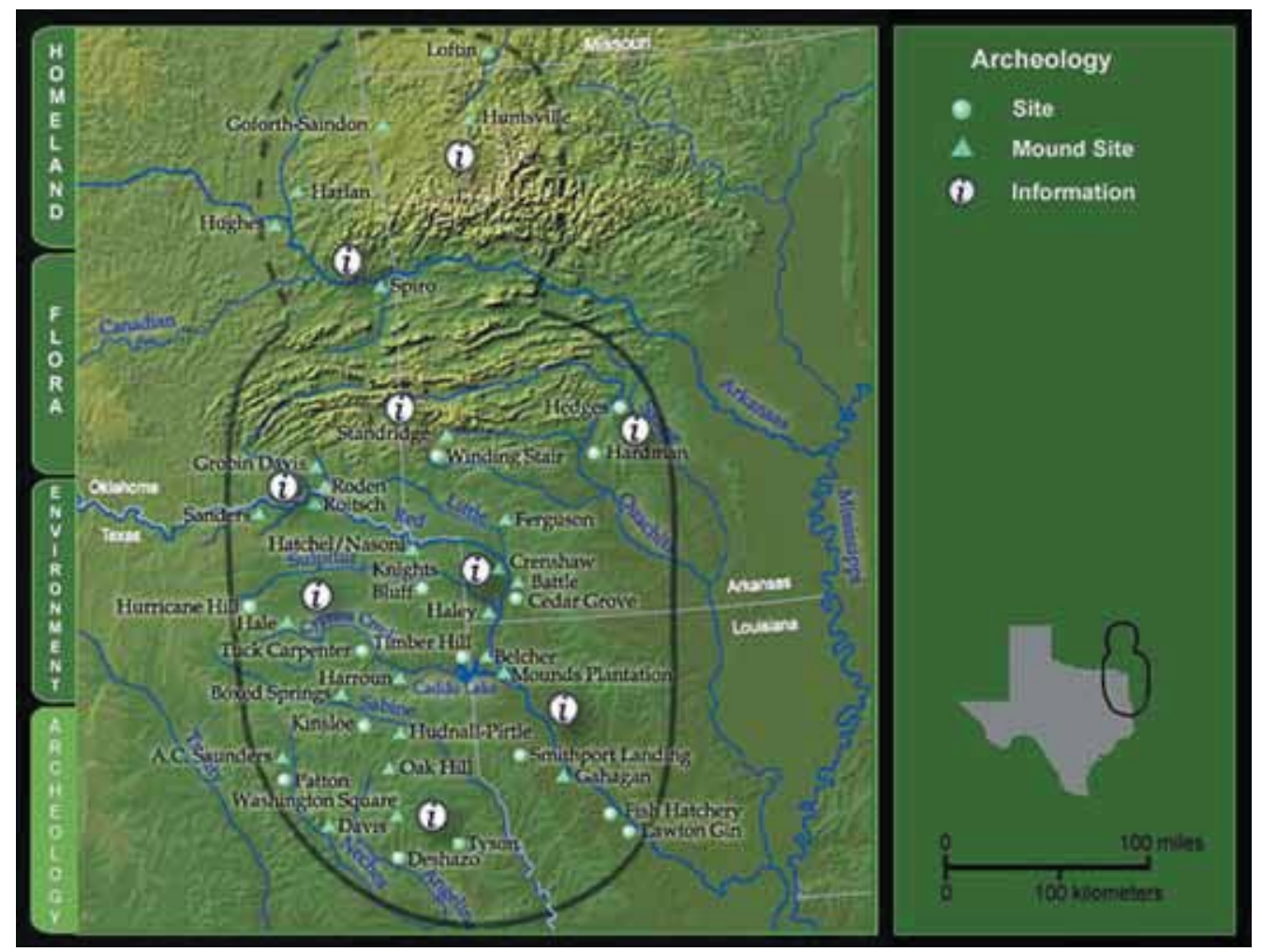

Figure 1b. The Caddoan culture area in Arkansas, Louisiana, Oklahoma, and Texas (image from Texas Beyond History; http://www.texasbeyondhistory.net/tejas/map/index.html ). 


\section{Arkansas River Caddoan Chronology}

Brown (1996:27) has presented recent refinements in chronology for the Fort Coffee area, which can be extended to the Arkansas River basin Caddoan cultures. The Evans phase serves to define an early pre-mound construction time at Spiro and has generally been applied to early Caddoan cultural expressions elsewhere in the Arkansas River basin and generally falls within A.D. 950 - A.D. 1000. This is followed by the Harlan phase, which is viewed as the dominant cultural expression in the Arkansas River basin from A.D. 1000- A.D. 1250. In Brown's sequence, the Harlan phase is succeeded by Norman (A.D. 1250-A.D. 1350) with Norman being supplanted by Spiro (A.D. 1350-A.D. 1450). The final phase in this sequence is Fort Coffee (A.D, 1450-A.D. 1600) when mound activities cease and highly ritualized religious practices are abandoned. It should be kept in mind however, that these delineations are artifacts of archaeological interpretation. Phase differentiation is based upon distinctions in exotic ritual goods, funerary practices, and to some extent settlement distributions. It is not a case of people of the Harlan phase being replaced by the Norman phase (for example). Cranford's (2007) recent research points out that Harlan and Norman were occupied contemporaneously and it would appear here that the concept of phase means more in respect to which ceremonial center is the most prestigious rather than a major change in people's ways of life.

\section{The Arkansas River Caddoan Database}

The Arkansas River Caddoan database consists of some 500 residential and mound sites in the region. Data for this analysis were derived from the site files maintained by the Oklahoma Archeological Survey, archival data of the WPA investigations in eastern Oklahoma between 1936 and 1942 (c.f., Rogers 1978), investigations conducted by the Oklahoma River Basin Survey under the supervision of Dr. Robert Bell between 1947 and 1970, Burt Purrington's (1971), Don Wyckoff's (1980), and Charles Rohrbaugh's (1982) dissertation data, Brown's (1996) seminal study of Spiro, and other more recent investigations resulting from directed research as well as cultural resource management studies (c.f., Rogers, Wyckoff, and Peterson 1989). Analysis of these data does not come without caveats. First of all, the data used in this analysis only pertain to Oklahoma sites in the Arkansas River basin and can only be extrapolated to the remainder of the region in western Arkansas with caution. Second, there are obvious Type I and Type II errors within the data. Type I errors are cases where sites that contain Caddoan components but were not sufficiently documented and were omitted from the database. There are also some sites included in the analysis that may have been erroneously documented as Caddoan sites (Type II errors). For example, Woodland sites in Delaware County hold shelltempered ceramics - a condition generally viewed as characteristic of Spiro phase settlements. Third, this must be viewed as a coarse-grain analysis that largely ignores more refined temporal considerations due to many sites having little chronometric data beyond relative dating by material assemblage (arrowpoint styles and ceramic typology). There is also a difficulty in that Fort Coffee phase components are frequently superimposed on earlier Harlan, Norman, and Spiro phase occupations. Despite these limitations, the data are amenable to construction of a basic Caddoan "architectural grammar" and cultural landscape analysis. This also represents the first attempt at developing a comprehensive GIS visualization of the Caddoan cultural landscape that includes both residential and ceremonial places.

\section{Comparative Examination of the Arkansas river Caddoan Landscape}

The Arkansas River drainage basin presents the pattern of a broadly dispersed constructed cultural landscape. While the Ozark Highlands are a part of the natural landscape, they do not serve as serious constraints in construction of the cultural landscape (as does the Ouachita Mountain in southeastern Oklahoma; Brooks 2008). Although stream valleys in the interior of the Ozark Highlands are highly constricted and narrow, 
this is less true where the Ozarks are dissected by major river systems. Here, valleys are generally broad, providing variable opportunities for the building of villages, mounds, and centers. This more accessible natural landscape (construction-wise) may potentially affect where centers are placed as religious or political considerations could have more influence than natural factors.

Examination of the some 500 sites revealed four basic forms of the constructed cultural landscape. The first is residential sites that may range from the isolated farmstead to larger villages/towns. Attempting to create some type of residential hierarchy should be approached with caution however, as in some cases, what distinguishes a farmstead or hamlet from a larger settlement is simply the extent of archaeological work conducted. The second form is that of single mounds. A third form is that of multiple mounds, all of the same structural type. The last form is that of multiple mounds exhibiting different structural type. All of these mound forms can occur with or without residential occupations. Residential occupation associated with the presence of built mounds is complicated and further discussion of this issue is presented later in the paper.

In examining the concept of an "architectural grammar" for the Caddoan cultural landscape, one question I had was whether there was a difference in natural landscape locations selected for residential places versus mounds or centers. Analysis of this question presented no clear results. A complication in this analysis was the large number of sites in the Arkansas River basin that were inundated by lake construction (1940s-1970s) which affected the reliability of documenting natural landscape attributes. In general, it appeared that only two variables had any causal relationship to construction of the cultural landscape. The first was soils: the higher the agricultural suitability indices, the greater the site densities. However, there seemed to be little distinction in soil selection whether it represented a residential place or a mound location. The other variable that exhibited some differential selection was width of the stream valley. Most multiple mound centers were situated in larger portions of the river valleys. From a practical standpoint, if you are constructing a large multi-mound center, it is desirable to have greater area available for construction of this "sacred" place.

\section{Distinctions in the Architectural Grammar}

Comparison of the constructed cultural landscape of the Arkansas River basin has resulted in the recognition of quantitative as well as qualitative differences that can be discussed in respect to the four basic forms previously identified (Figure 2). Table 1 presents the quantitative expression of these differences.

Table 1. Distribution of the Constructed Landscape by Region.

\begin{tabular}{|l|l|}
\hline Constructed Landscape & Arkansas River Basin \\
\hline Residential Places & 483 \\
\hline Single Mound Places & 6 \\
\hline $\begin{array}{l}\text { Multiple Mound Places } \\
\text { Same Construction Type }\end{array}$ & 2 \\
\hline $\begin{array}{l}\text { Multiple Mound Places } \\
\text { Different Construction Types }\end{array}$ & 6 \\
\hline Totals & 497 \\
\hline
\end{tabular}




\section{Residential Places}

Residential places are the dominant expression, representing $97 \%$ of the constructed cultural landscape (Figure 2). The Arkansas River basin's residential places exhibit a range from hamlets such as the Plantation site in McIntosh County (Briscoe 1977) to more sizeable villages/towns of 15-20 houses such as Littlefield in Le Flore County (Brown 1984). Larger towns/villages are thought to contain populations of roughly 200 people per village. However, this should not be construed to mean that population densities paralleled those of the Mississippi River valley. The Arkansas River basin populations were substantially lower than those found to the east. Even in the "metropolitan area" surrounding Spiro, it is doubtful that populations exceeded 2500 to 3000 people. These residential places also appear homogenously distributed across stream valleys. This distribution also includes the occupation of upland rock shelters - particularly in the period after mound building has been discontinued (the Fort Coffee phase). However, taking into consideration the more dispersed nature of residential places within the Arkansas River basin, they also exhibit clustering around mound centers.

Previously I had stated that this analysis would ignore attempts at chronological refinement. Despite this limitation, there are a few comments that can be made regarding the distribution of residential places on the cultural landscape through time. As previously noted by Bell (1984) and Brown (1996) the Caddoan cultural expression reaches its maximum spatial expression during the Harlan phase with the ensuing Norman and Spiro phases reflecting retraction and retrenchment. There are exceptions to this general pattern. For example, there are two extreme outliers during the Spiro phase that are found in central Oklahoma (Figure 3). The Nagle site (340K4; Schaeffer 1957) in Oklahoma County and possibly the Alcorn site (34ML1) in McClain County are example of Caddoan populations' westward movement. In the case of these two sites, they are some 100 miles from the nearest Caddoan ceremonial center (Eufaula Mound). Location of the Nagel site suggests movement up the North Canadian River for some unspecified purpose. It represents a burial population without an accompanying residential occupation. Schambach (1999) suggested Nagel represented a trading outpost, whereas I subsequently offered Nagel as an example of a group of missionaries that met with a hostile reception (Brooks 2006). The Alcorn site contains both a burial population and a residential occupation. The Caddoans occupying the Alcorn site would have traveled up the (South) Canadian River roughly the same distance as the group at Nagle. I find it intriguing that these sites are almost on a north-south line in their distance from the Arkansas River basin Caddoan homeland.

There are some distinctions in residential places that can be identified at the architectural level. During the Harlan and Norman phases, dwellings are square to rectangular with four-center post construction. During the Spiro phase, this architecture is revised to more rectangular dwellings with a two center-post arrangement. To date, there has been no consensus as to the meaning of the change in centerpost arrangement. There is no evidence for intramural storage facilities in residential structures during Harlan-Norman-Spiro phase occupations, suggesting that some level of resource sharing at the community level is operating. Residential structures of the Fort Coffee phase continue the rectilinear twocenter-post architecture. However, Fort Coffee phase dwellings have more formalized central hearth construction and the presence of intramural storage facilities. Presumably, by Fort Coffee times, greater privatization of goods is occurring with concomitant decreases in community level resource sharing. 


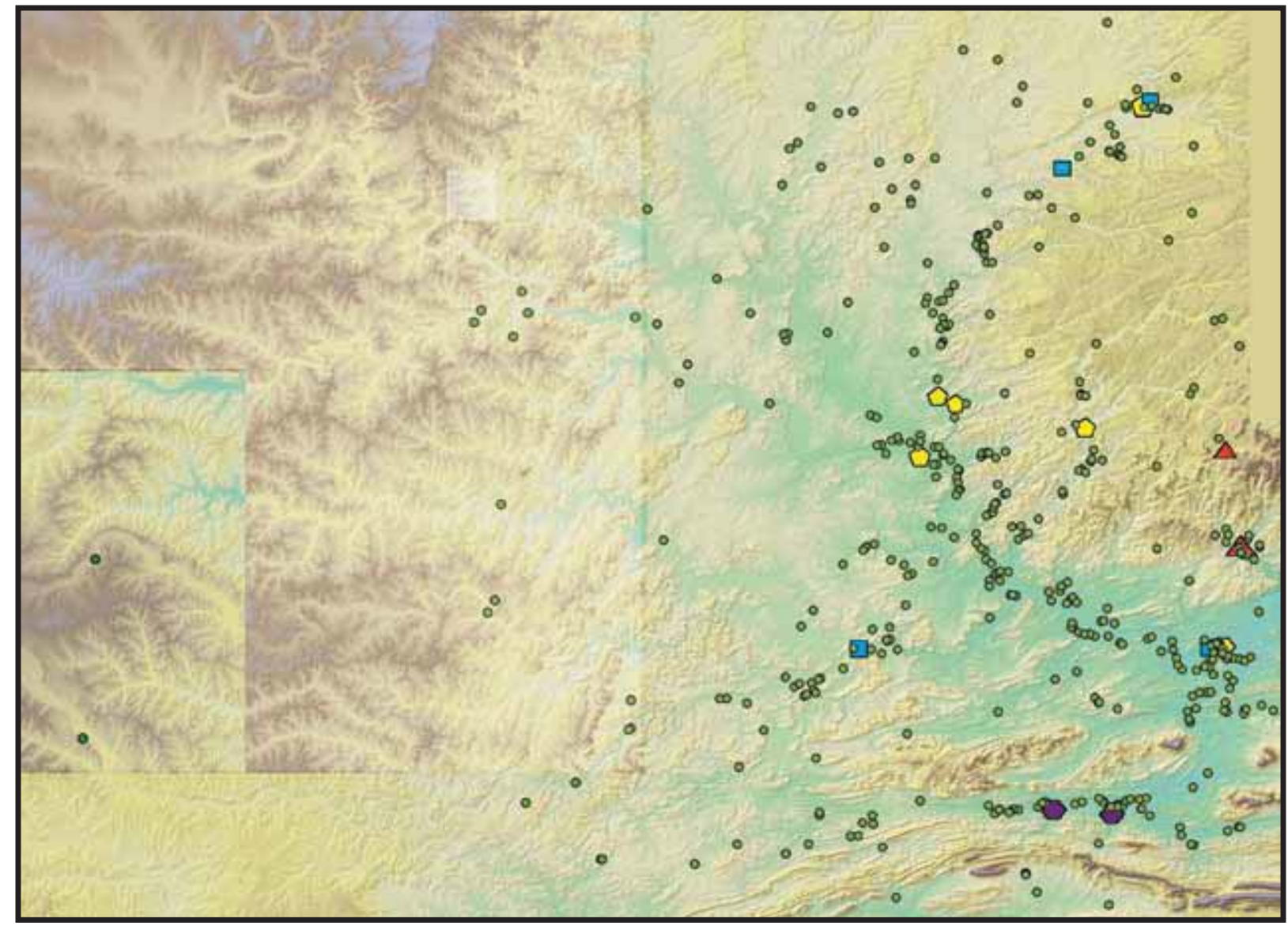

Figure 2. Caddoan cultural landscape, Arkansas River Basin. Key: Green Circles=residential places, Red Triangles=single mound centers w/o residential occupation, Blue Squares=single mound places with residential occupation, Purple Hexagons=multiple mound places of the same construction type, and Yellow Pentagons=multiple mound places of different construction type.

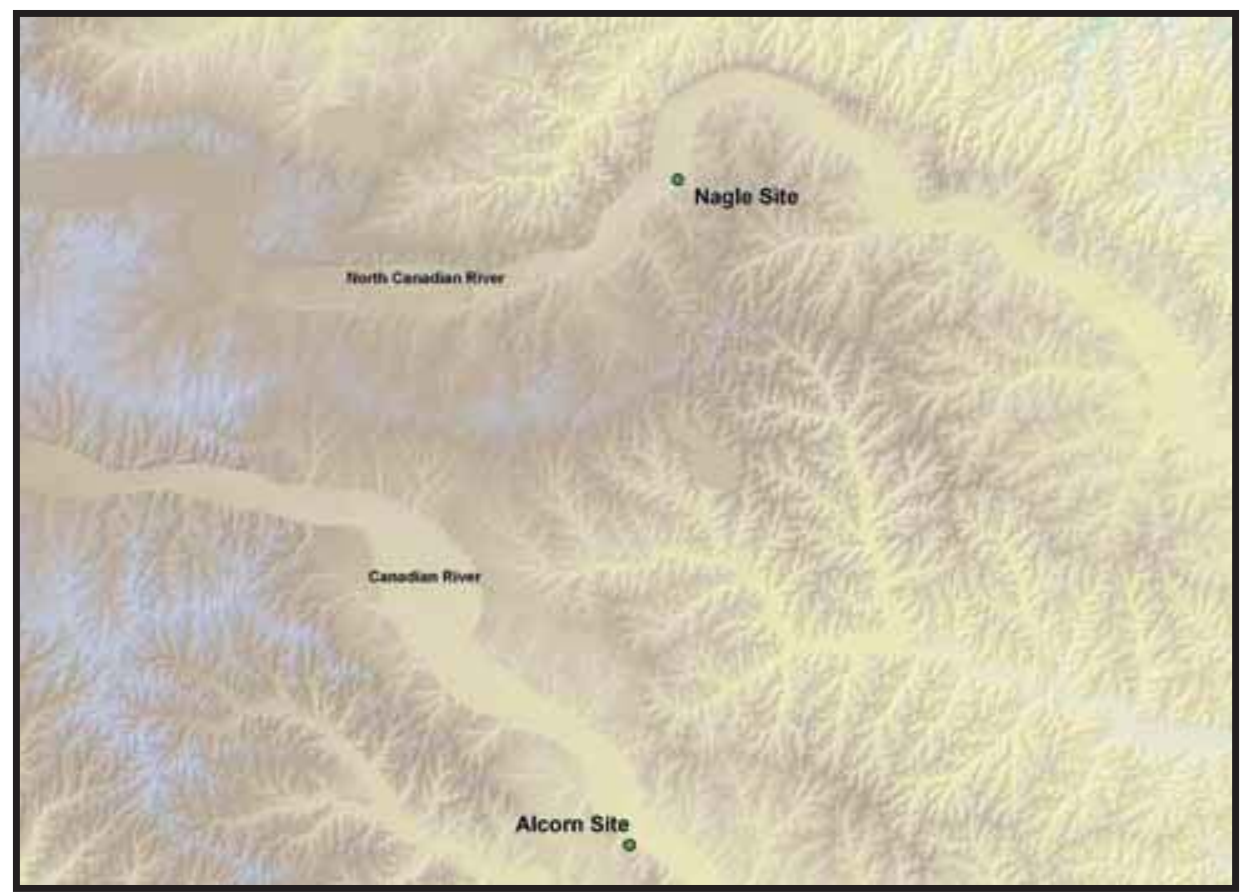

Figure 3. Location of Nagle and Alcorn sites in central Oklahoma. 


\section{Single Mound Places}

There are six single mound places in the Arkansas River basin. The patterning among these single mound centers is relatively complex with three different expressions of single mound places. This is in marked contrast to the Red River basin where the predominant pattern is of single platform mounds or burned house structures. At Eufaula Mound in McIntosh County, on the western periphery of the Arkansas Basin, a burial mound occurs in association with an adjacent village (Figure 4; Orr 1945). The WPA excavated Eufaula Mound in 1940 under the supervision of Kenneth Orr. Orr (1945) specifically notes that only the single mound is present and is surrounded by village debris. The mound is four and a half feet tall and 174 feet by 110 feet in area. David Baerreis (in Purrington 1971) is also cited as thinking that a plowed-down burial mound was present at the Huffaker site in Delaware County. He thought that the highly circumscribed spatial arrangement of the burials and their slight superposition (in some cases) was indicative of a mound that had been leveled by cultivation. Another possibility is that this is the burial mound excavated by Thoburn (1931). Although Thoburn describes the excavations as taking place on the Reed property, he notes only the one mound, making no mention of the other mounds present at Reed. The Huffaker property adjoins that of Reed so it is very possible for property boundaries to have been confused, especially in 1926.

Two other single mound places contain platform mound structures with associated villages. These are the Lillie Creek site in Delaware County (Figure 5; Purrington 1971; Vogel 2002) and the Skidgel Mound two miles to the west of Spiro Mounds in Le Flore County. Purrington (1971), using Baerreis' fieldnotes, describes the Lillie Creek Mound as five feet in height and roughly 40 feet in length. Brown (1996) describes Skidgel as 20 feet high and 125 feet in diameter. The Skidgel Mound probably represents a portion of the greater Spiro ceremonial center pattern with the Cavannah Mound, some nine miles to the east in Fort Smith, Arkansas representing the paired mound. It should be noted however that the Cavannah Mound shows no evidence of an associated village. In the case of Skidgel and Lillie Creek, the residential occupation could be that of priestly elites rather than individuals of less privileged status.

The remaining two single mound sites are the Lee Creek Ceremonial Center in Sequoyah Count and Ewing Chapel Mound in Adair County (Figure 6). Both of these single mound sites with platform structure have somewhat unusual characteristics. They both occur in the uplands overlooking stream valleys. All other single mound places (and multiple mound ones as well) occur within alluvial valley systems. According to Muto (1980), the Lee Creek Ceremonial Center is 12 feet in height and 134 by 105 feet in circumference. Wyckoff (1980) reports Ewing Chapel to be about four and a half feet high and 75 feet by 45 feet in circumference. Neither Lee Creek nor Ewing Chapel appears to have associated residential occupations. Recent investigations at Lee Creek by a 2006 University of Oklahoma field school revealed evidence of temporary occupations rather than habitation features (Pluckhahn 2008). Thus, it appears that groups periodically traveled to Lee Creek for ceremonies but did not reside at the site with perhaps only a small group of priestly elites or perhaps an individual representing more permanent residents. It is also possible that there were no residents and the mound and facilities were abandoned except for ceremonial occasions. Although no investigations have been conducted at Ewing Chapel, an adjacent residential occupation has not been noted. Considering the degree of variation from other single mound places, Ewing Chapel and Lee Creek may have a much different role in the Arkansas River basin Caddoan religious system or perhaps may be affiliated with the Ozark Highlands Caddoan pattern (Kay, Sabo, and Merletti 1989). 


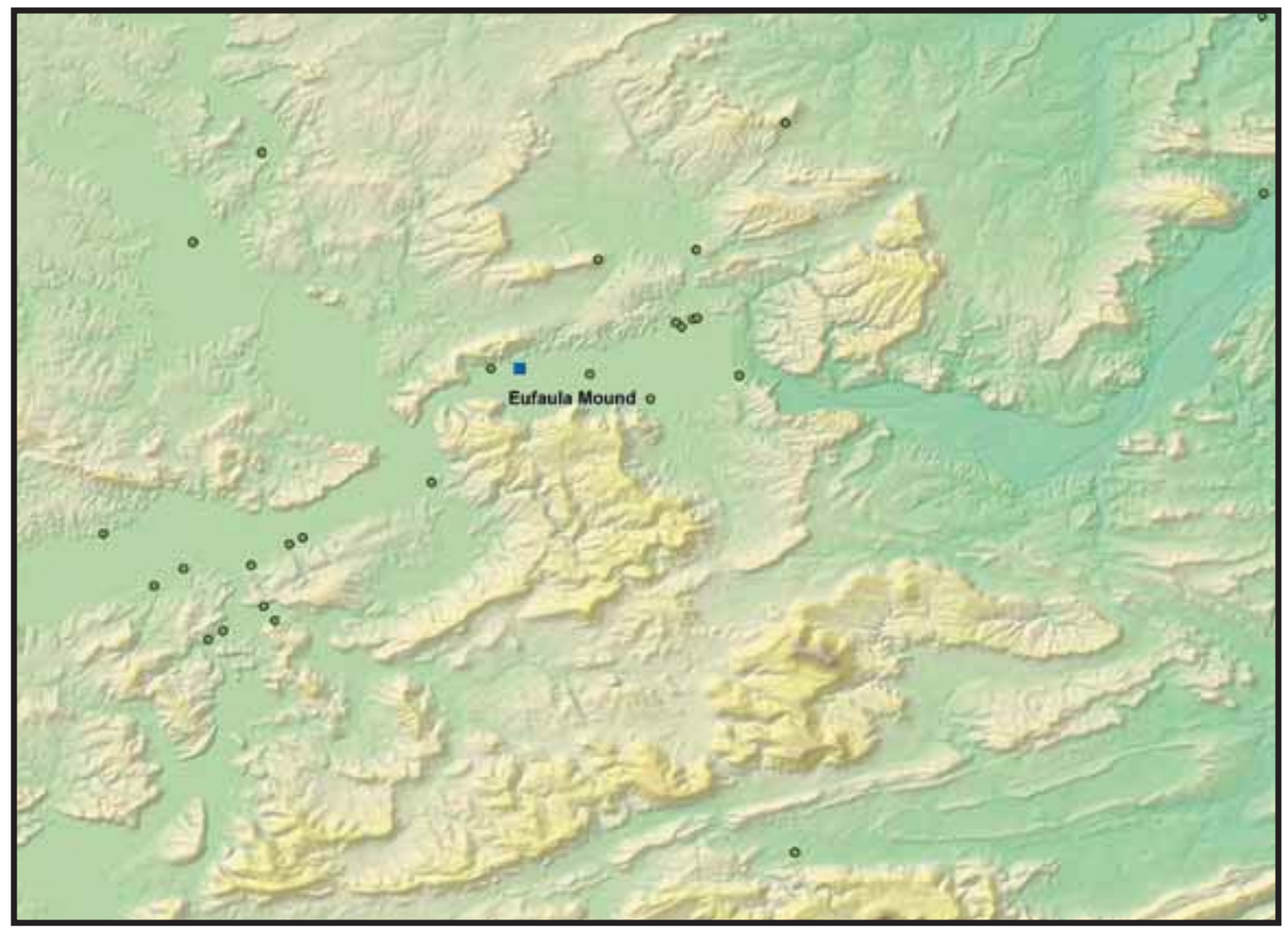

Figure 4. Eufaula Mound (represented by blue rectangle in center of figure).

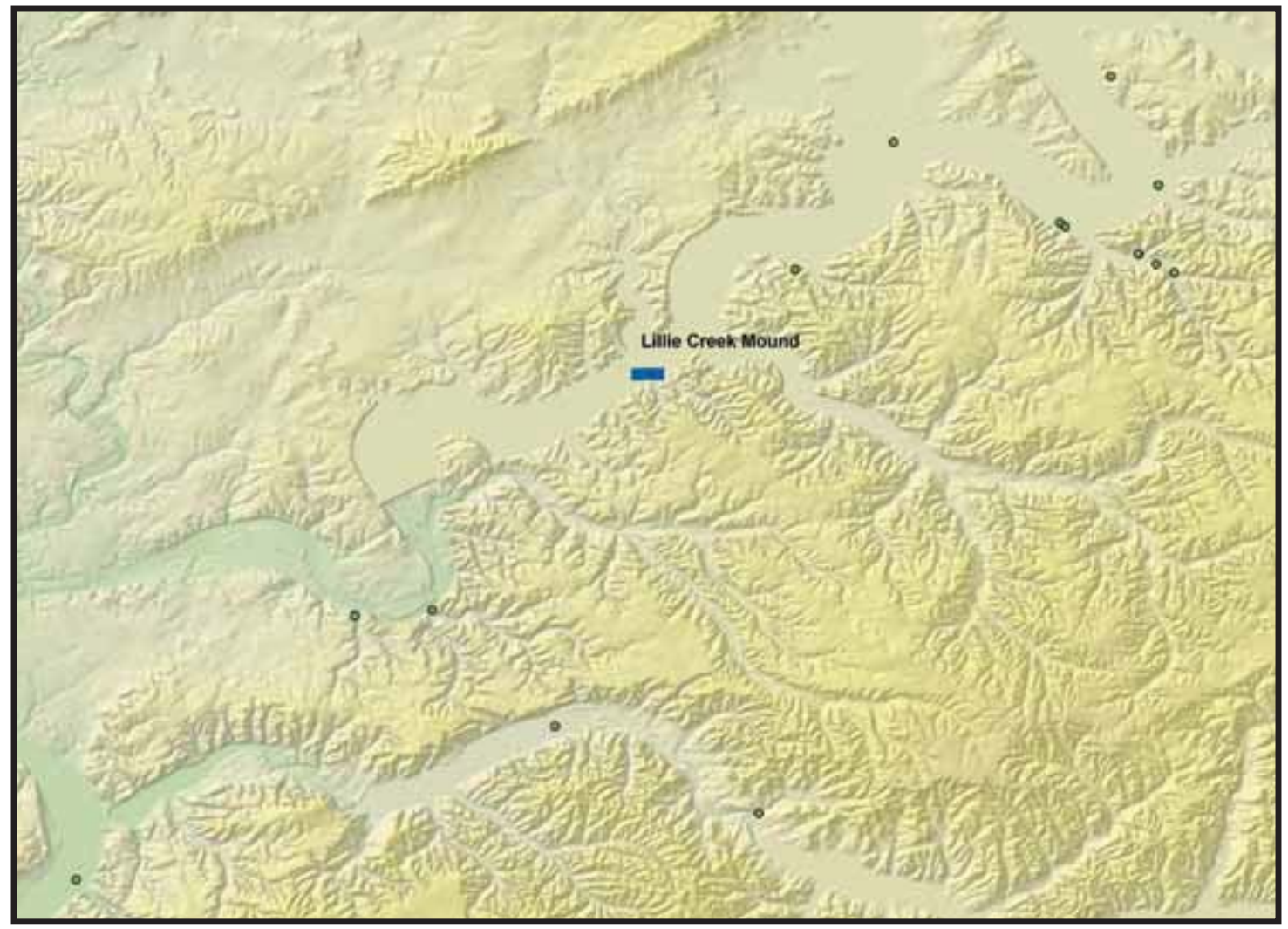

Figure 5. Natural landscape setting of the Lillie Creek Mound. 
Another interesting facet of Ewing Chapel and Lee Creek concerns the surrounding residential places (Figure 6). The Lee Creek Ceremonial Center has a number of associated residential sites that are located in Little Lee Creek valley below the mound. However, Ewing Chapel can claim only one nearby residential site on Evansville Creek that appears to be associated. Does this reflect a coverage error in that no professional survey has been conducted along Evansville Creek that would identify residential places? (Funds for a survey of Evansville Creek have recently been awarded and fieldwork will take place in late 2009/2010.) Or, is Ewing Chapel an anomaly in that it has no associated residential sites - much like Cavannah Mound in South Fort Smith?

Multiple Mound Places: Same Construction Type

There are only two multiple mound places where the mounds represent the same construction type. These are the Sol Thompson mounds and the Holson Creek mounds in Le Flore County (Figure 7). This is quite unlike the pattern in the Red River basin where there are numerous multiple mound places with the same mound construction type. There were apparently two (or three?) small mounds at the Holsen Creek site although others might have been destroyed prior to the site's documentation by a WPA survey crew. None of these were described as burial mounds. As reported by Wyckoff (1980), the mounds are roughly three feet in height and 60 feet in diameter. Burials with exotic funerary goods were reportedly found eroding from the creek bank south of the easternmost mound although they did not apparently come from a mound context (Mayo 1975). Brown (1996) reports multiple house mounds from Sol Thompson based on WPA fieldnotes. In the account given by Brown (1996:169) Mound 2 contained two structures spanning the Harlan and Spiro phases. Mounds 1 and 3 contained multiple Spiro phase structures. However, these represent demolished structures that more resemble charnel house mounds than the mounds at Holsen Creek. Brown also suggests that a larger mound at Sol Thompson represents a possible burial mound. Galm's (1978:222-230) discussion of the WPA's work at Sol Thompson refers to the three houses and only one constructed mound. From these accounts, Sol Thompson may represent a multiple mound place with repeated constructions of similar mound structures or a multiple mound site containing two different mound construction types.

Residential occupation accompanying the Holson Creek and Sol Thompson mounds is also open to further examination. Galm (1978) as well as Mayo and Neal (1975) report the presence of habitation debris at Holson Creek. It is unclear from Brown (1996:169-170) and Galm's (1978:222-230) discussion of Sol Thompson whether the site contains normal habitation debris or remains that would be associated with priestly elites' presence.

From a landscape perspective, there is an interesting aspect to the two multiple mound places with similar mound construction. Both are found in close proximity in Le Flore County on the northern periphery of the Ouachita Mountains. This pattern of multiple small charnel or house mounds does not occur elsewhere in the Arkansas River drainage system although it is the typical pattern of the Caddo in the Red River drainage. 


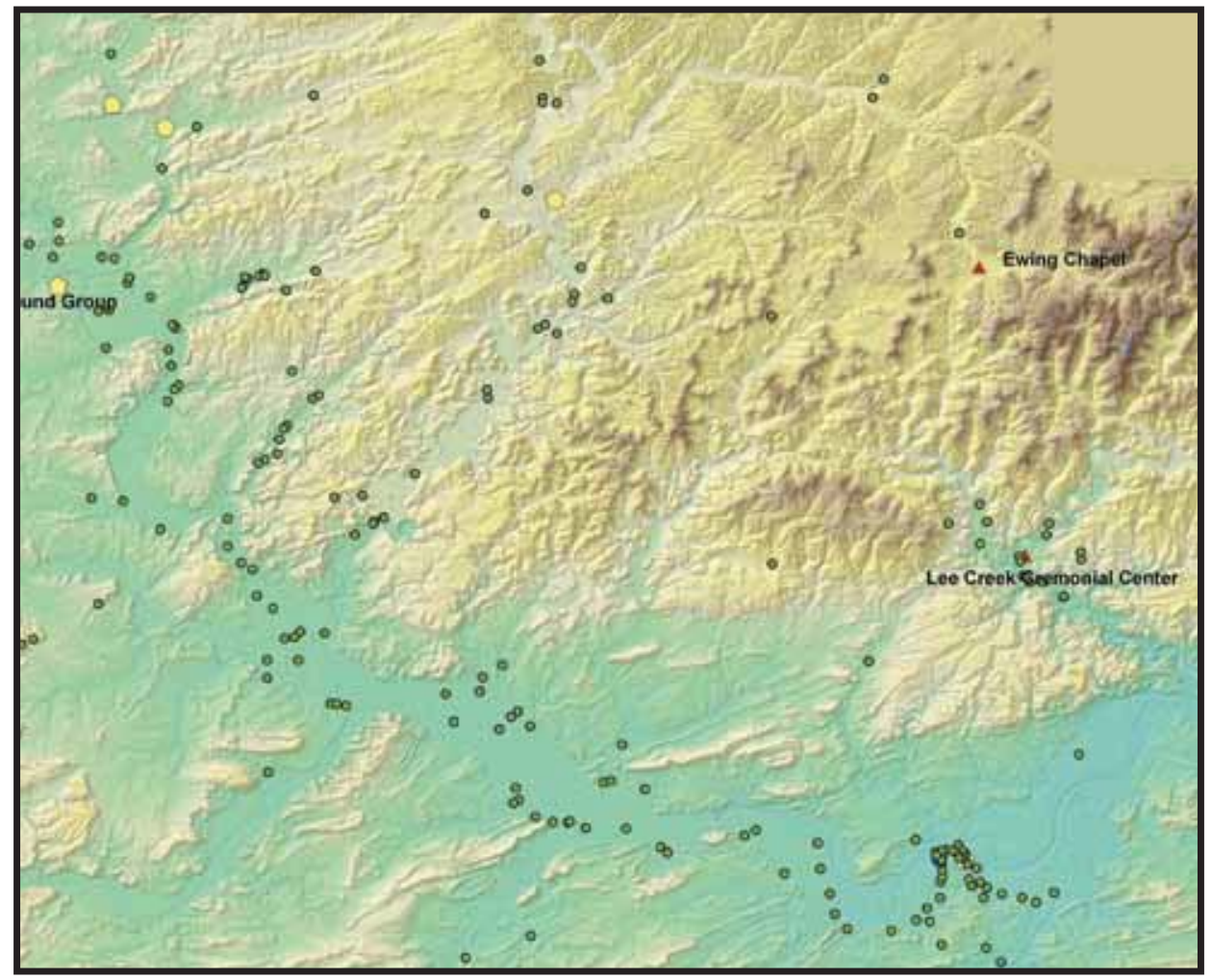

Figure 6. Lee Creek Ceremonial Center and surrounding residential places and Ewing chapel's absence of nearby residential places..

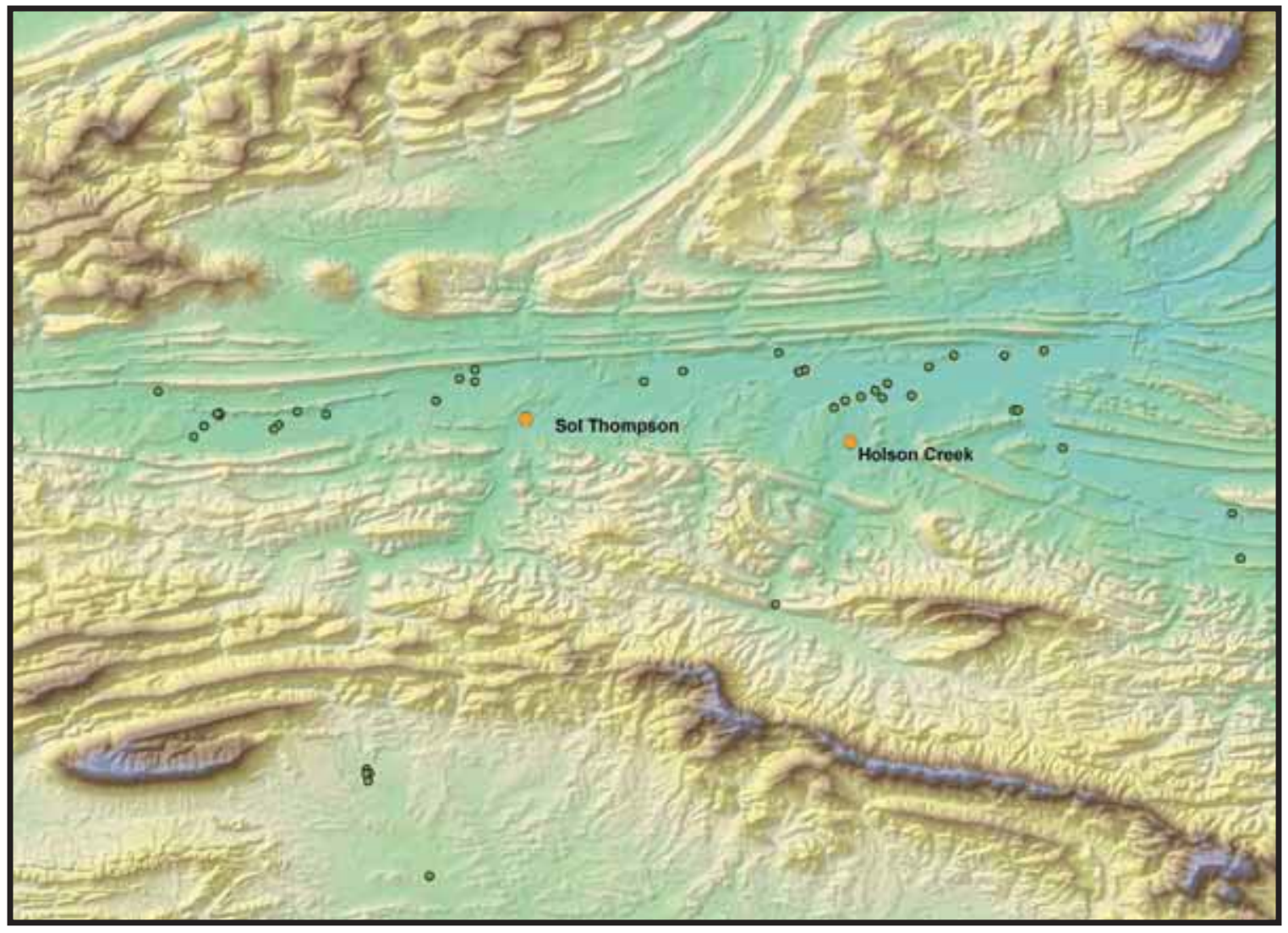

Figure 7. Natural landscape setting of the Sol Thompson and Holson Creek Mounds. 
I suggest that there are six multiple mound places containing different types of constructed mounds. In the Arkansas River basin, three of these places have been highly publicized: Spiro, Norman, and Harlan. In the past, some of other multiple mound sites have been viewed as only containing a single mound or a single type of constructed mound. However, previous studies sometimes did not fully consider earlier information on these sites or did not consider alternative explanations for the current mound configuration.

The Hughes site in Muskogee County has been described as having a platform mound some 19 feet in height and 175 feet in diameter (as described from the WPA field notes, Bell 1974). Lynn Howard of the University of Oklahoma, as part of WPA investigations, excavated this mound in 1938. The mound excavated by Howard is the only one noted in the WPA work. But, as Vogel (2006) notes, there are clearly two mounds present (Hughes and Fort Davis). An earlier description of the site in 1910 describes it as having seven mounds (Parsons 1910). Parsons describes two large mounds averaging some 14 feet in height and roughly 40 feet in diameter at their apex (he perhaps meant base?). He also mentions that the mound closest to the river (Hughes) has five smaller associated mounds. These mounds averaged about four feet in height and eight feet in diameter (based on the height, the diameter estimate is clearly in error). One mound has survived the urban expansion of Muskogee and currently has a protected location within a subdivision (Figure 8). Although it is close to the location of the Fort Davis mound, it would appear to be substantially smaller than 15 feet in height. It more approximates the size of the smaller mounds surrounding Hughes. There is also an isolated artifact that indirectly presents collaborative information for the presence of additional structural types of mounds at Hughes. Bell (1956) has described a large flint clay effigy pipe (the Chunky Player) that is in the collections of the St. Louis Art Museum. This effigy pipe was reportedly removed from a mound near Muskogee around 1905. These large effigy flint clay pipes have only been recovered from burial mound contexts in Oklahoma. I would suggest that this pipe came from such a mound at the Hughes site although it is unclear which one. There are also a significant number of residential places surrounding the Hughes site (Figure 9).

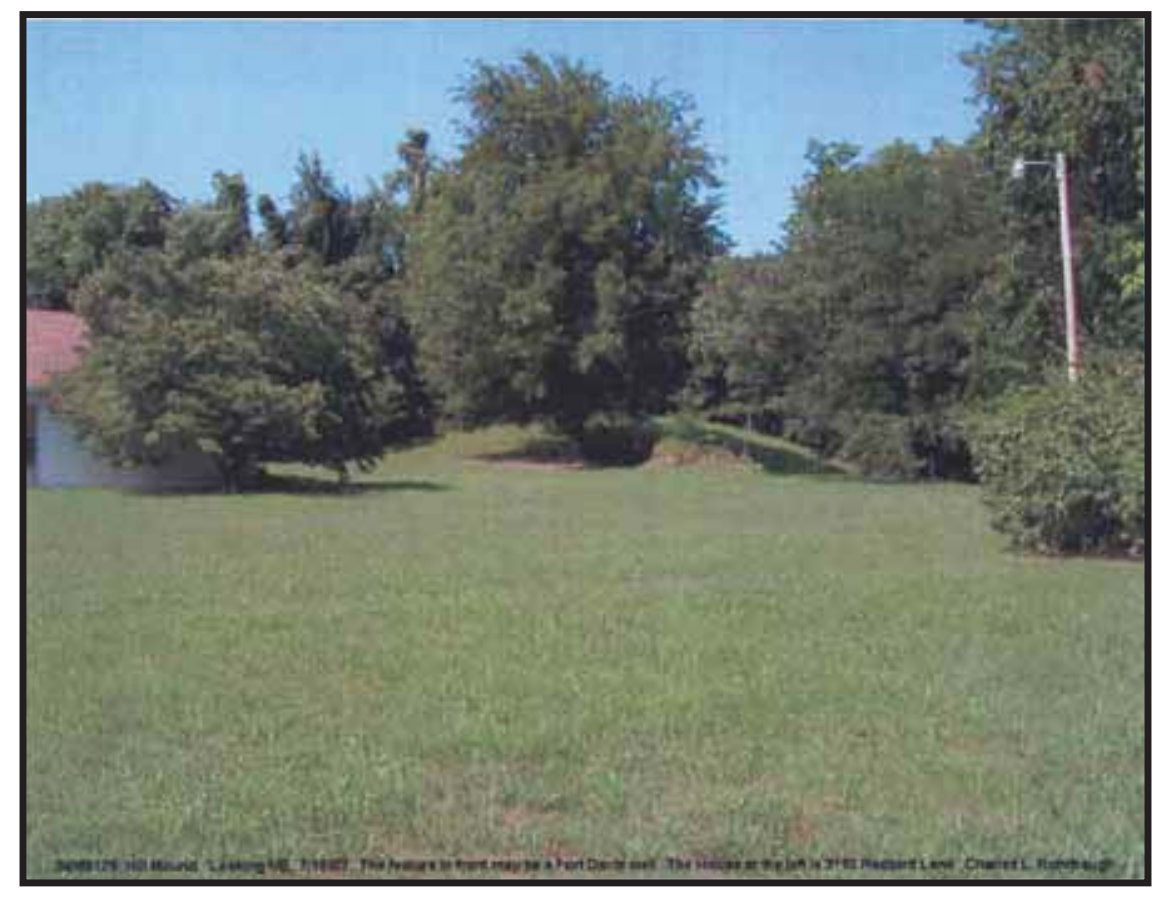

Figure 8. Surviving Fort davis mound at the Hughes Mound Group. 


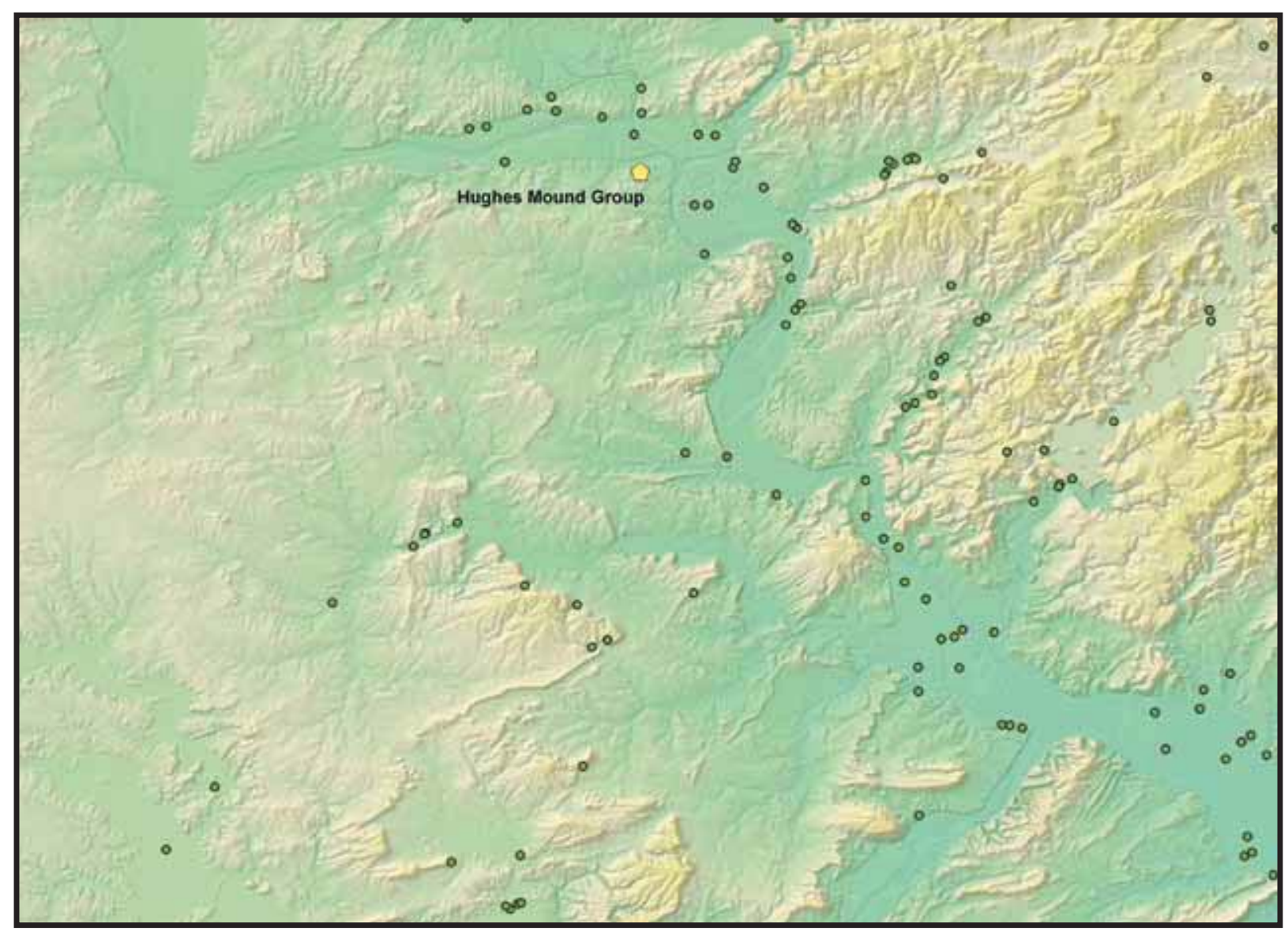

Figure 9. Residential places associated with the Hughes Mound Group. 
A similar situation exists at the Brackett site in Cherokee County (Figure 10). This site is frequently described as containing a single platform mound and associated village. Howard also excavated Brackett in 1938 as part of the WPA work program. Howard (1940) describes a single conical mound seven feet high and 100 feet in diameter. There was also a cemetery area at Brackett that contained some 25 individuals within a circumscribed area some 40 feet in diameter. At least some of the individuals appear to have been superimposed on one another. Funerary offerings with the individuals included copper covered ear spools, large bifaces, and ceramic vessels. Howard's discussion of the site suggests that the cemetery may have represented a plowed-down burial mound. A map of the Brackett site illustrates two sets of superimposed house patterns immediately adjacent to the conical mound (Figure 11). I suspect that these represent ploweddown charnel house mounds similar to House Mound 5 at Spiro (Rogers 1982a).

Another multiple mound place with different structural mound forms is the Reed site in Delaware County (Figure 12). The Reed site has not received the attention that it merits, probably due to the sketchy nature of the WPA documentation. I would note that David Baerreis considered Reed to be a highly significant mound site for the upper Grand River, perhaps paralleling Spiro for the northern Arkansas River basin. The first reputed work at the Reed site was by Joseph Thoburn in 1925 (Thoburn 1931). Thoburn stated that he excavated a pyramidal mound some 25 feet in diameter. Due to the presence of large numbers of funerary offerings in the mound, it is presumed that this represented a burial mound. There are difficulties with Thoburn's work though. He makes no mention of other mounds at the site and subsequent investigations by the WPA in 1937 did not report finding evidence of Thoburn's excavations. Of course, 12 years had passed since Thoburn dug at Reed and farming practices as well as subsequent looting could have obscured much of the evidence for his work from the WPA. As mentioned earlier, Thoburn also could have excavated a mound on the adjoining Huffaker property rather than at Reed. This would explain the absence of any mention of additional mounds as well as Baerreis' belief that there was a plowed-down (or perhaps excavated?) burial mound at Huffaker.

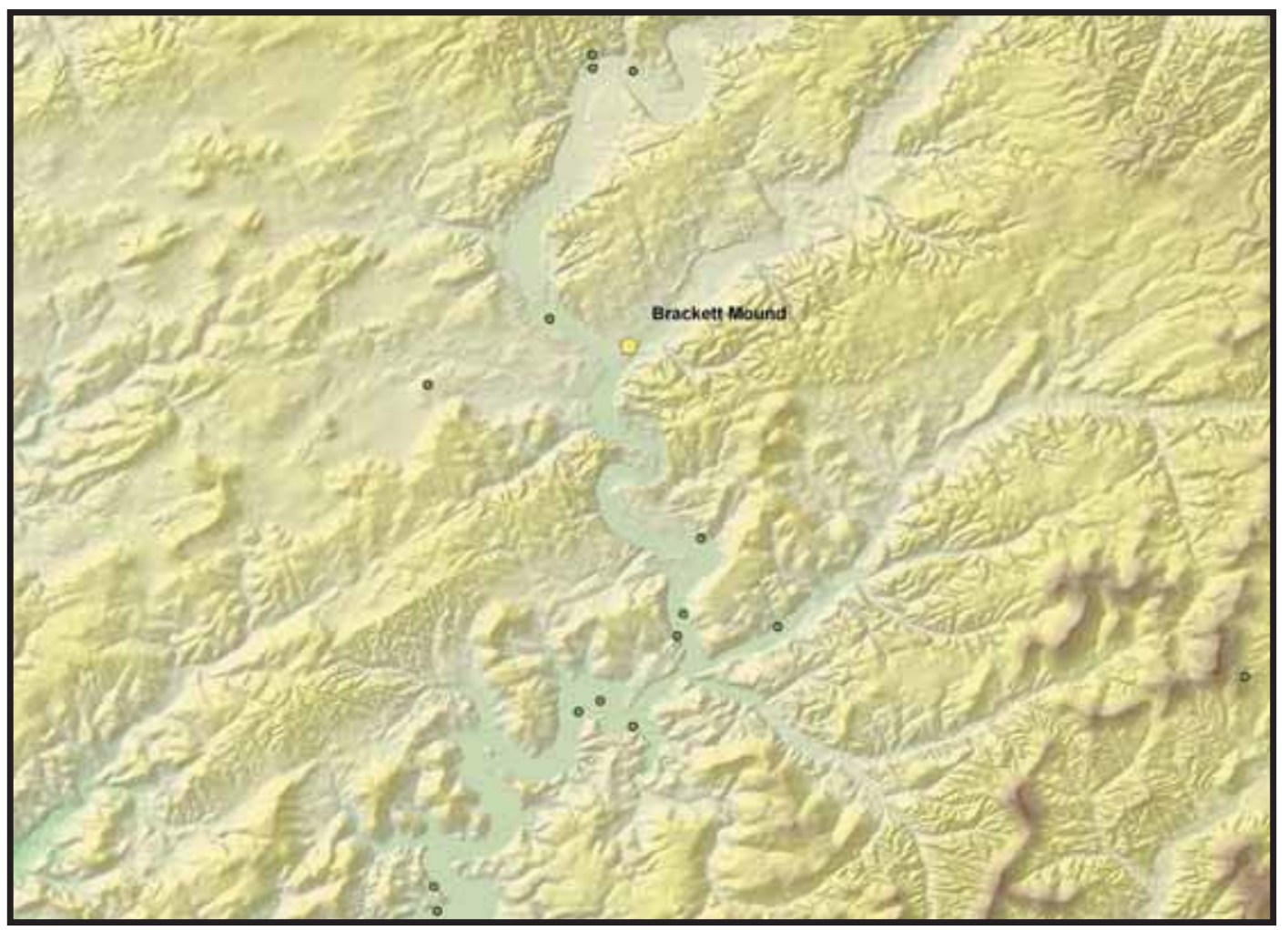

Figure 10. Natural landscape setting of the Brackett Mound Group. 


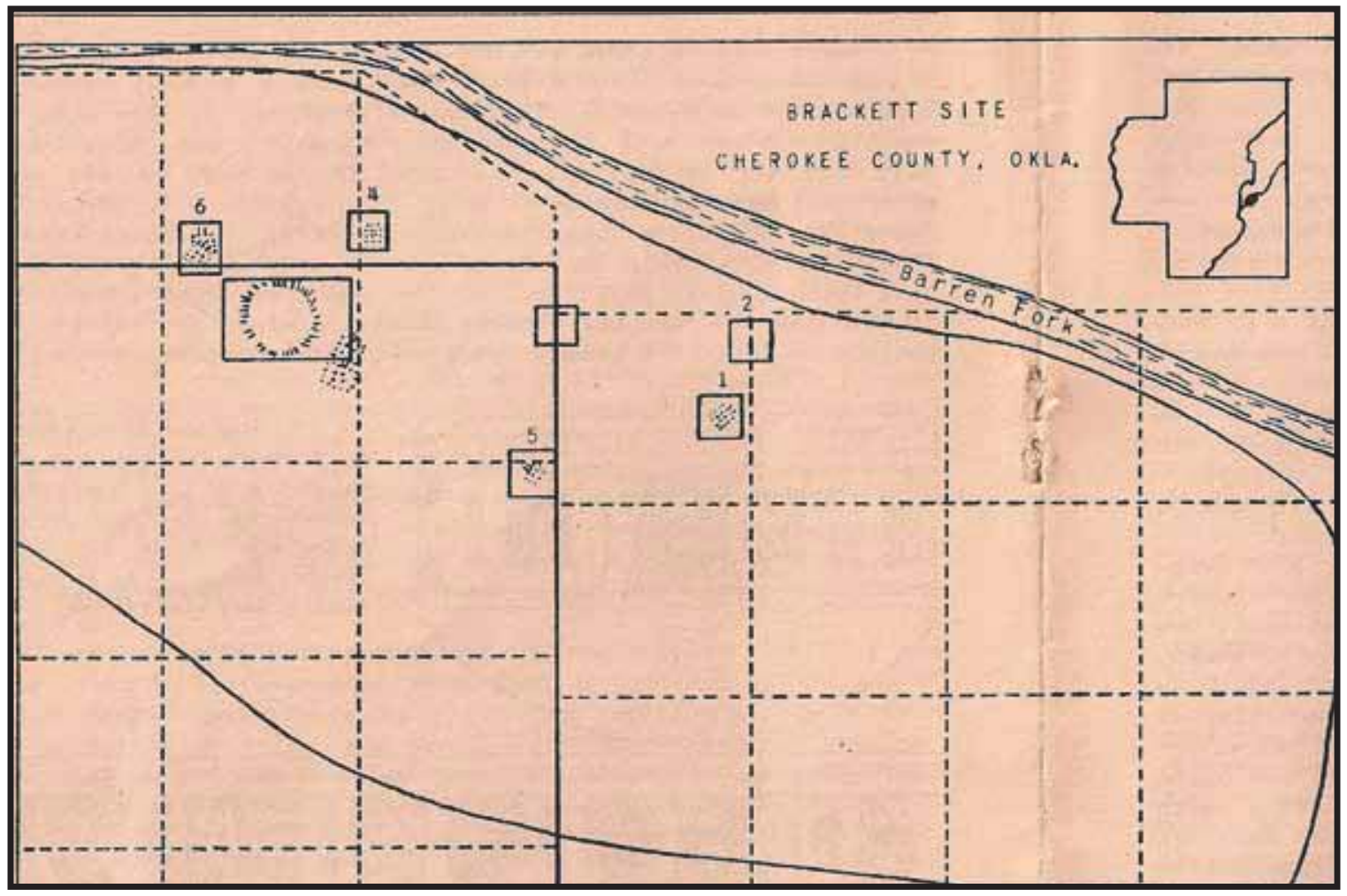

Figure 11. Brackett site map (note superimposed houses adjacent to the mound (Howard 1940:5).

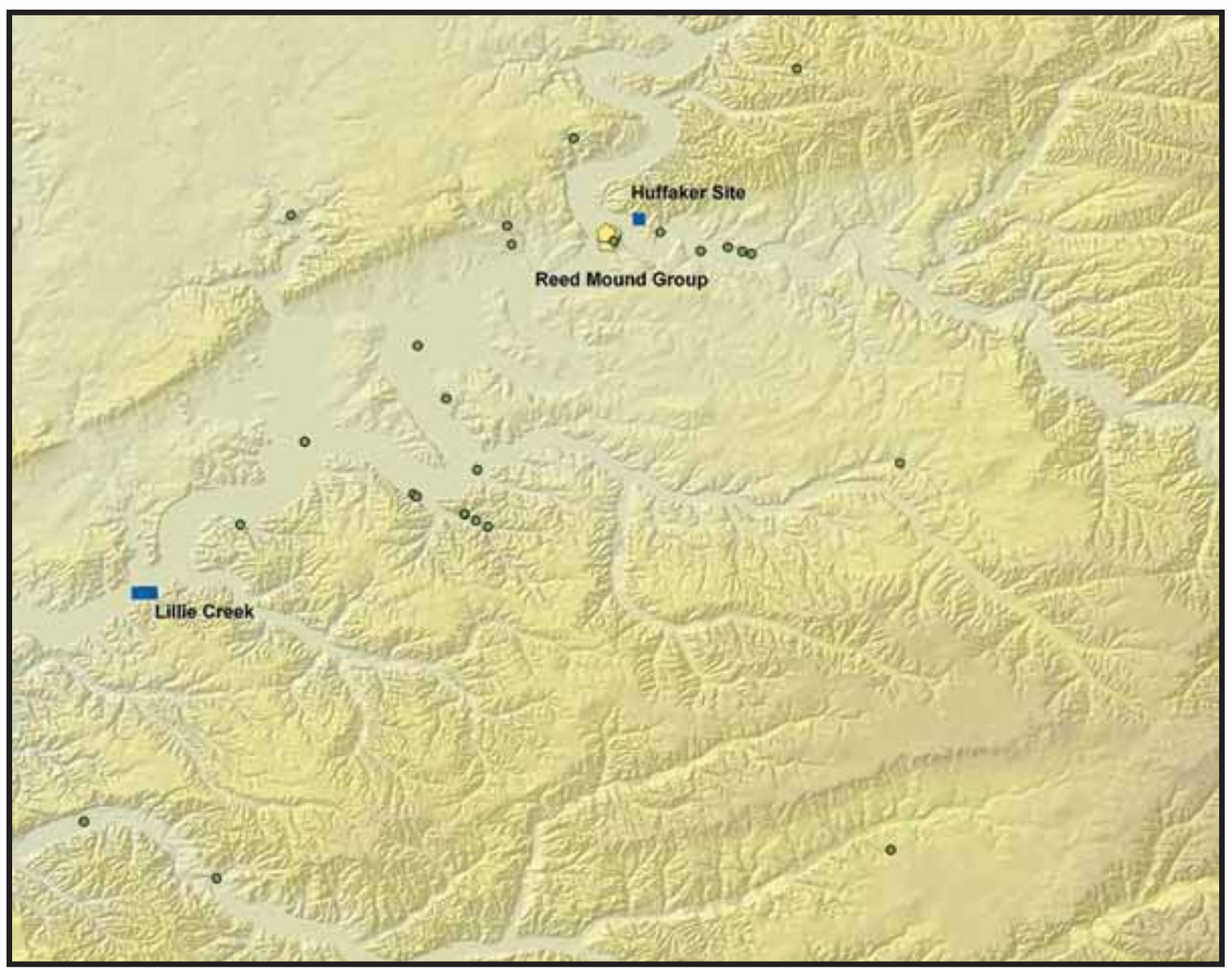

Figure 12. Natural Landscape setting of the Reed Mound Group. 
The WPA conducted excavations at the Reed site from 1937 to 1939 under the supervision of David Baerreis. Based on Purrington's (1971) analysis of Baerrreis' field notes, there were 11 work areas at the Reed site. These included a platform mound some seven feet in height and 115 feet in diameter, a conical burial mound about four feet in height and 60 feet in diameter, and an area considered a "house mound (Area B-2)" that included 12 houses that were superimposed on one another with an adult and a child burial. Other areas contained midden debris and additional house patterns some of which were superimposed. At least some of the superimposed house floors probably represent the remnants of charnel house mounds although perhaps not recognized as such in Purrington's analysis.

The three remaining places with multiple mounds of different structural form are Harlan (Bell 1972), Norman (Albert et al. 2000), and Spiro (Brown 1996). The WPA excavated the Norman site (1934-1936) under the supervision of Joe Finkelstein (Bauxar). Spiro, also a WPA excavation (1936-1940) was conducted under numerous supervisors. The Harlan site was excavated by Bell in 1949-1950 and subsequently in 1958. Spiro and Harlan have received considerable analytic attention while Norman has only recently been the focus of other than a cursory overview (cf. Cranford 2007). Investigations at Harlan revealed the presence of a cojoined burial mound, a platform mound, and five house mounds (Bell 1972). The co-joined burial mound was seven feet in height with diameters of 50,35, and 35 feet for the three joined conical mounds. The largest mound was of a platform structure being 14 feet high and 130 by 160 feet (Bell 1972). The five house mounds ranged from $3 \frac{1}{2}$ to $5 \frac{1}{4}$ feet in height and averaged 78 feet in diameter. It is difficult to assess the exact number of mounds at the Norman site (Albert 2000). However, there were at least two co-joined mounds, a conical mound, and perhaps three or more house mounds. The largest of the co-joined mounds (Mound I) is a platform mound rather than a burial mound and is seven feet high with two conical areas 90 and 100 feet in diameter. The other co-joined mound was a burial mound estimated to be around 10 feet in height with the two conical areas being 70 feet and 45 feet in diameter (Finkelstein 1940). The remaining conical mound is a platform structure and has a diameter of 140 feet and was approximately six feet in height (Albert 2000). Because of limited and unrevealing tests of the three small mounds (approximately $1 \frac{1 / 2}{2}$ feet high), it is uncertain whether these represent house mounds or natural features on the landscape (Albert 2000). The Spiro site consists of a co-joined burial mound, two platform mounds, and at least nine smaller house mounds. Rogers (1982b) also mentions the presence of additional small midden mound-like features that occur around the plaza west of the Brown Mound. Spiro has been thoroughly analyzed by Brown (1996) and the following mound descriptions are drawn from this work. The largest mound at Spiro (the Craig Mound) consists of four co-joined conical burial mounds. They range from roughly 34 feet in height to around 12 feet (the smallest) and extend for roughly 350 feet. The larger of the two platform mounds (Brown) was approximately 15 feet in height and 200 feet by 175 feet. The smaller platform mound (Copple) is estimated to have been eight feet high and around 60 feet in diameter. Dimensions of the nine house mounds range from roughly five feet in height to about two feet and from 70 feet to around 35 feet in diameter.

Harlan, Norman, and Spiro all contain plazas that functioned as ceremonial spaces for the mound arrangements. It cannot be ascertained whether Hughes, Reed, and Brackett contained plazas. There are hints of such a spatial arrangement at Reed but little exists to suggest their presence at the other two sites.

\section{Interpretation of the Architectural Grammar}

Analysis of the Arkansas River Caddoan landscapes has demonstrated notable differences in the distribution of mound forms and residential occupations. Single mound places in the Arkansas River basin have variable expressions ranging from burial mounds to platform mounds. At least two of the single mound places exhibit no evidence for permanent residential occupation. However, they are clearly ritualized locations 
that nearby communities visit on some as yet undefined cycle. Multiple mound places of the same mound structure are rare in the Arkansas River basin but, based on current information, represent either burned house mounds or charnel house locations. These places appear to also have residential populations. Six multiple mound places with different structural forms are strategically located in the Arkansas River basin. These structural elements include one or more platform mounds, a burial mound (typically co-joined), one or more charnel house mounds, and a plaza. Each of these multiple mound centers is very much like the other. In fact, tabulation of the size of platform mounds, burial mounds, and house mounds display considerable correspondence (Table 2). Examination of platform mound heights in particular is suggestive of two size groupings ( $4 \frac{1}{2}$ feet to 8 feet and 12 to 20 feet) that may reflect built stages (the original being the platform structure and the second being the mounding over of the platform). There is more variation in the size of the burial mounds where they range from four feet to 10 feet in height.

Table 2. Dimensions of Temple, Burial, and House Mounds, Arkansas River Drainage Basin Caddoan Mounds and Centers.

\begin{tabular}{|c|c|c|c|}
\hline Mound & Temple & Burial & House \\
\hline Eufaula & & $4.5^{\prime} / 174 \times 110^{\prime}$ & \\
\hline Lillie Creek & $5^{\prime} / 40^{\prime}$ long & & \\
\hline Skidgel & $20^{\prime} / 125^{\prime}$ diameter & & \\
\hline Lee Creek & $12^{\prime} / 134^{\prime} \times 105^{\prime}$ & & \\
\hline Ewing Chapel & $4.5^{\prime} / 75^{\prime} \times 45^{\prime}$ & & \\
\hline Holson Creek & & & $3 \prime / 60^{\prime}$ diameter \\
\hline Sol Thompson & & & $\ldots$ \\
\hline Hughes & $19^{\prime} / 175^{\prime}$ diameter & & 4'/8' diameter \\
\hline Brackett & 7'/100' diameter & & \\
\hline Reed & $7^{\prime} / 115^{\prime}$ diameter & $4^{\prime} / 60^{\prime}$ diameter & .....- \\
\hline Harlan & $14^{\prime} / 130^{\prime} \times 160^{\prime}$ & $\begin{array}{l}7^{\prime} / 50^{\prime}, 35^{\prime}, 35^{\prime} \\
\text { diameter elements }\end{array}$ & $\begin{array}{l}3.5^{\prime}-5.25^{\prime} / 78^{\prime} \\
\text { diameter (mean) }\end{array}$ \\
\hline Norman & $\begin{array}{l}7^{\prime} / 90,100^{\prime} \\
\text { diameter elements } \\
6^{\prime} / 140^{\prime} \text { diameter }\end{array}$ & $\begin{array}{l}10^{\prime} / 70,45^{\prime} \\
\text { diameter elements }\end{array}$ & $1.5^{\prime} / ?$ \\
\hline Spiro & $\begin{array}{l}15^{\prime} / 200^{\prime} \times 175^{\prime} \\
8^{\prime} / 60^{\prime} \text { diameter }\end{array}$ & $34^{\prime}-12^{\prime} / 350^{\prime}$ long & $\begin{array}{l}2^{\prime}-5{ }^{\prime} / 35^{\prime}-70^{\prime} \text { diameter } \\
\text { range }\end{array}$ \\
\hline
\end{tabular}

The first dimension represents mound height and the second width/length or diameter.

Craig Mound is not included in this range due to extreme variation from the remainder of the burial mounds (34 feet at its highest point; Brown 1996). The size variation in burial mounds may reflect a number of conditions including the number of elites from surrounding residential places, the population of priestly elites at the ceremonial center, the duration of use for the burial mound, and distance to the nearest other center with a burial mound (although the burial mounds at Harlan and Norman are the largest outside of Craig Mound). The range in size for house/charnel house mounds is from approximately one and a half feet in height to five feet. In most instances, this variation in height is reflective of sequential rebuilding episodes.

During their early history the mound centers had a residential occupation. By their later histories, though, they are thought to have been occupied only by priestly elites with clusters of surrounding residential communities. At one point, Brown (1996) argued that the premier center was sequential with Harlan being the earliest, followed by Norman, and subsequently by Spiro. More recent evidence would suggest that all three 
held prominence, although by the mid 1400s Spiro clearly was more prestigious (Cranford 2007). In viewing the architectural grammar of the centers, I would argue that there is a "structural grammar" that accompanies the architectural aspect. This structural grammar involves elements embedded within the practices of the ceremonial center. The structural presence includes the use of charnel houses for holding deceased priestly elites as well as a place for associated rituals; the burial mound (and possible affiliated crematorium) where the deceased are ultimately interred; platform mounds where priestly leaders preside over ceremonies; and the use of the plazas for ceremonies where less hierarchical practices are involved. Brown, Bell, and Wyckoff (1978) argued for a ranked ordering of places for Arkansas River Caddoan society. However, it appears to me that it is more of a structure where a blueprint is initially established to meet a particular set of religious/ political requirements. Moreover, this structure is perceived as being established early in the life history of the mound center-with each center evolving to meet this structure. Plazas are clearly an important part of Arkansas River basin religious practice (although not well identified by early work at the Hughes, Reed, and possibly Brackett sites). Some mound places do not follow this blueprint (e.g, Eufaula, Lillie Creek, Lee Creek, Ewing Chapel, Holson Creek, and Sol Thompson). However, rather than viewing these as secondary places, it is more reasonable to consider them as operating under a different architectural grammar. For example, Lee Creek and Ewing Chapel occur on high terraces overlooking the alluvial valleys and appear to not have residential occupants. I would suggest that rather than these being secondary centers that they represent a different blueprint that has a different relationship to Arkansas River basin Caddoan religious/political practices or perhaps are more articulated with the Ozark Highlands mound groups (e.g., Goforth-Sainden, Huntsville). Holson Creek Mounds and Sol Thompson also appear of a different pattern and as I suggested earlier may be more related to Ouachita Mountains Caddo practices. The two single mound locations that are most difficult to explain in regard to deviance in the architectural grammar are Lillie Creek and Eufaula. Lillie Creek could represent the beginnings of a new center evolving from the Reed Mounds. Eufaula Mound is more problematic. Assuming that there is a consistent structure of practice in placing the priestly elite in charnel houses prior to final disposition in the burial mound, where are the charnel houses at Eufaula? And, while there are instances of platform mounds with the absence of burial mounds, there is no other case of a burial mound found without an accompanying platform mound (excepting the confusing situation at Brackett). I would argue here that the exceptionally sandy soils at Eufaula, combined with agricultural activity might have resulted in this center being significantly degraded prior to documentation.

From these observations, I am suggesting that the Arkansas River Caddoan architectural grammar holds more in common with the Mississippian World than does their Red River Caddo counterparts practices to the south (as suggested by Schambach). While the architectural grammar is more consistent with a Mississippian theme, this does not necessarily imply that Mississippian society populations were actively directing the structural grammar associated with Arkansas River Caddoan political and religious practices. This relationship between the high church of Mississippian religious history and Arkansas River Caddoans remains poorly understood. While this paper has examined the constructed landscape, I should also point out that ideational landscapes also exist and merit attention. At Spiro, the final construction of Brown Mound, thought to be a representation of the nearby Round Mountain, hints of symbolic referents as do petrogylphs found at a rock shelter near Spiro. 


\section{References Cited}

Albert, Lois E.

2000 The Norman Site: Descriptions. Caddoan Archeology 11: (1-2): 23-68.

Bell, Robert E.

1957 Stone Pipe Found in Muskogee, Oklahoma. Newsletter of the Oklahoma Anthropological Society 5 (3):6-7.

1974 Mounds and Fieldwork Near Muskogee, Oklahoma. Newsletter of the Oklahoma Anthropological Society 22 (8):6-9.

1972 The Harlan Site, Ck-6, A Prehistoric Mound Center in Cherokee County, Eastern Oklahoma. Memoir No. 2, Oklahoma Anthropological Society.

1984 The Arkanasas River Caddoan: The Harlan Phase. In Prehistory of Oklahoma, edited by Robert E. Bell, pp. 221-239, Academic Press, New York.

Briscoe, James

1977 The Plantation Site: An Early Caddoan Settlement in Eastern Oklahoma. Oklahoma Highway Archaeological Survey, Papers in Highway Archaeology 3.

Brooks, Robert L.

1996 The Arkansas River Valley: A New Paradigm, Revisionist Perspectives and the Archaeological Record. Caddoan Archeology Newsletter 7(1): 17-27.

2006 From Mounds to Monasteries: A Look at Spiro and Other Centers Through the Use of Metaphor. Caddo Archaeology 15:41-58.

2008 Distribution of Caddo Settlements on the Natural Landscape: A View from Southeastern Oklahoma. Paper presented at the $65^{\text {th }}$ Annual Southeastern Archaeological Conference, Charlotte.

Brown, James

1984 Arkansas River Caddoan: The Spiro Phase. In Prehistory of Oklahoma, edited by Robert E. Bell, pp. 241-263, Academic Press, New York.

1996 The Spiro Ceremonial Center. Memoirs of the Museum of Anthropology, University of Michigan, Number 29, Ann Arbor.

Brown, James A., Robert E.Bell, and Don G. Wyckoff

1978 Caddoan Settlement Patterns in the Arkansas River Drainage. In Mississippian Settlement Patterns, edited by Bruce D. Smith, pp. 169-200. Academic Press, New York.

Bruseth, James E., Diane E. Wilson, and Timothy K. Perttula

1995 The Sanders Site: A Spiroan Entrepôt in Texas? Plains Anthropologist 40:223-236.

Cranford, David

2007 Political Dynamics of Closely Spaced Mississippian Polities in Eastern Oklahoma: The Harlan (34CK6) and Norman (34WG2) Sites. M.A. Thesis, University of Oklahoma. Norman.

Finkelstein, J. Joe

1940 The Norman Site Excavations Near Wagoner, Oklahoma. The Oklahoma Prehistorian 3 (3): 2-15.

Galm, Jerry R.

1978 Archaeological Investigations at Wister Lake, Le Flore County, Oklahoma. Archaeological Research and Management Center, Research Series 1.

Howard, Lynn

1940 Preliminary Report on Cherokee County, Oklahoma Archaeology. Oklahoma Prehistorian 3(1):29. 


\section{References Cited (Cont.)}

Kay, Marvin, George Sabo III, and Ralph Merletti

1989 Late Prehistoric Settlement Patterning: A View from Three Caddoan Civic-Ceremonial Centers in Northwest Arkansas. In Contributions to Spiro Archaeology: Mound Excavations and Regional Perspectives, edited by J. Daniel Rogers, Don G. Wyckoff, and Dennis Peterson, pp. 129-157, Oklahoma Archeological Survey, Studies in Oklahoma's Past No. 16.

Lewis, R. Barry, Charles Stout, and Cameron B. Wesson

1998 The Design of Mississippian Towns. In Mississippian Towns and Sacred Spaces: Searching for an Architectural Grammar, edited by R.Barry Lewis and Charles Stout, pp. 1-21. University of Alabama Press, Tuscaloosa.

Mayo, Michael

1975 A Resurvey and Assessment of the Prehistoric Resources of Wister Lake, Le Flore County, Oklahoma. General Survey Report No. 15, Oklahoma River Basin Survey Project, Norman.

Muto, Guy R.

1980 The Habiukut of Eastern Oklahoma. Parris Mound, Part I, Phase I: An Archaeological Report. Oklahoma Historical Society, Series in Anthropology No. 3.

Orr, Kenneth

1945 The Eufaula Mound, Oklahoma: Contribution of the Spiro Focus. Masters thesis, University of Chicago, Chicago.

Parsons, Arthur R.

1910 Archaeological Notes (Mounds in Oklahoma). The Archaeological Bulletin 2:92-93, Council Grove, Kansas. (reprinted in the Newsletter of the Oklahoma Anthropological Society 3 (4): 4-5)

Perttula, Timothy D.

2009 Foreword: A Current Perspective on Caddo Archeology. In Classics in Texas Archeology, Volume 1: Caddo Archeology, Series editor, Timothy K. Perttula, pp. 5-18. Gustav Library, Davenport IA.

Pluckhahn, Thomas J.

2007 Archaeological Investigations in Spiro's Hinterlands: Testing of the Lee Creek Ceremonial Center Site (34SQ12), Sequoyah County, Oklahoma. Report submitted to the Oklahoma Historical Society, Oklahoma City.

Purrington, Burton L.

1970 The Prehistory of Delaware County, Oklahoma: Cultural Continuity and Change on the Western Ozark Periphery. Ph.D. dissertation, University of Wisconsin, Madison.

Rogers, J. Daniel

1978 Federally Sponsored Archaeological Work in Oklahoma Before World War II. Unpublished manuscript on file, Oklahoma Archeological Survey, Norman.

1982a Spiro Archaeology: 1980 Research. Oklahoma Archeological Survey, Studies in Oklahoma's Past 9.

1982b Spiro Archaeology: The Plaza. Oklahoma Archeological Survey, Studies in Oklahoma's Past 10.

Rogers, J. Daniel and George Sabo III

2004 Caddo. In Handbook of North American Indians: Southeast, edited by Raymond D. Fogelson, pp. 616-632. Smithsonian Institution Press, Washington D.C.

Rogers, J. Daniel, Don G. Wyckoff, and Dennis Peterson (editors)

1989 Contributions to Spiro Archeology: Mound Excavations and Regional Perspectives. Oklahoma Archeological Survey, Studies in Oklahoma's Past 16. 


\section{References Cited (Cont.)}

Rohrbaugh, Charles L.

1982 Spiro and Fort Coffee Phases: Changing Cultural Complexes of the Caddoan Area. Ph.D. dissertation, University of Wisconsin, Madison.

Schambach, Frank D.

1993a Some New Interpretations of Spiroan Culture History. In Archaeology of Eastern North America: Papers in Honor of Stephen Williams, edited by James B. Stoltman, pp. 187-230. Mississippi Department of Archives and History, Archaeological Report No. 25

1993b Spiroan Entrepôts and Beyond the Western Border of the Trans-Mississippi South. Caddoan Archaeology Newsletter 4(2):11-26.

1999 Spiro and the Tunica: A New Intepretation of the Role of the Tunica in the Culture History of the Southeast and the Southern Plains. In Arkansas Archaeology: Essays in Honor of Dan and Phyllis Morse, edited by Robert C. Mainfort and Marvin Jeter, pp. 169-224. University of Arkansas Press. Fayetteville.

Shaeffer, James B.

1957 The Nagle Site, Ok-4. Bulletin of the Oklahoma Anthropological Society 5:93-100.

Thoburn, Joseph

1931 The Prehistoric Cultures of Oklahoma. In Archaeology of the Arkansas River Valley by Warren King Moorehead, pages ??Department of Archaeology, Phillips Academy, Andover, Massachusetts.

Vogel, Gregory

2005 A View from the Bottomlands: Late Prehistoric Mound Centers and Their Relationship to the Landscape in the Northern Caddo Area. Ph.D. dissertation, University of Arkansas, Fayetteville.

Wyckoff, Don G.

1980 Caddoan Adaptive Strategies in the Arkansas Basin, Eastern Oklahoma. Ph.D. dissertation, Washington State University, Pullman.

1985 Spiro Mounds: Prehistoric Gateway, Present-Day Enigma. Stovall Museum of Natural History \& Oklahoma Archeological Survey, Norman. 